\title{
SCAFFOLDING ON STUDENT CONSTRUCTION ERRORS IN MATHEMATICS PROBLEM SOLVING
}

\author{
Isnania $^{1^{*}}$, Nizlel Huda ${ }^{2}$, Hariyanto ${ }^{3}$ \\ ${ }^{1,2,3}$ Department of Mathematic Education, Postgraduate Program, Universitas Jambi, Indonesia
}

*Corresponding author: isnania500@gmail.com

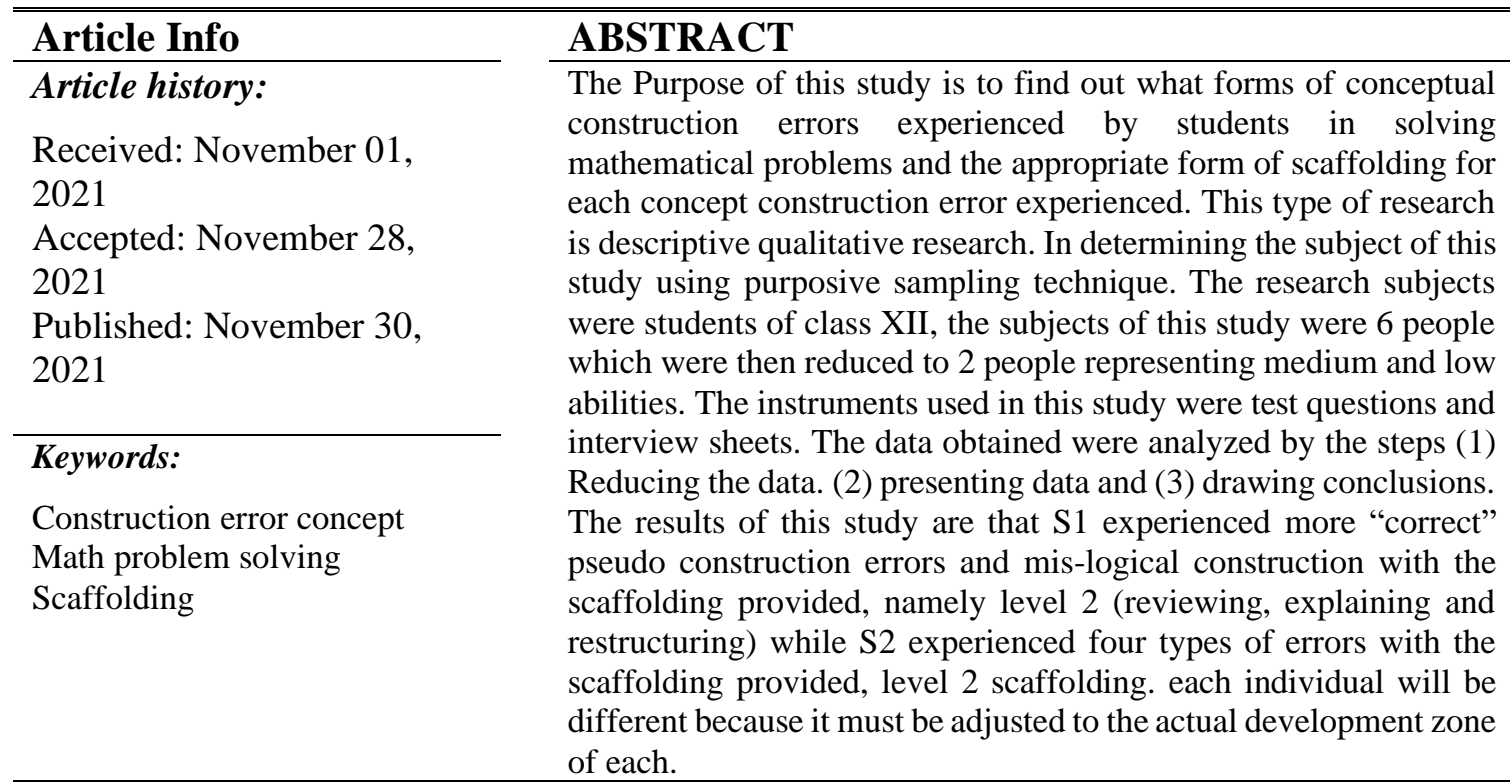

\section{SCAFFOLDING PADA KESALAHAN KONSTRUKSI KONSEP SISWA DALAM PEMECAHAN MASALAH MATEMATIKA}

\section{Kata Kunci:}

Kesalahan konstruksi konsep

Pemecahan masalah

matematika

Scaffolding

\section{ABSTRAK}

Penelitian ini bertujuan untuk mengetahui apa saja bentuk-bentuk kesalahan konstruksi konsep yang dialami siswa dalam pemecahan masalah matematika dan bentuk scaffolding yang sesuai untuk masing-masing kesalahan konstruksi konsep yang dialami. Jenis penelitian ini adalah penelitian deskriptif kualitatif. Dalam menentukan subjek penelitian ini menggunakan teknik purposive sampling. Subjek penelitian adalah siswa kelas XII, subjek penelitian ini berjumlah 6 orang yang kemudian direduksi menjadi 2 orang yang mewakili kemampuan sedang dan rendah. Instrumen yang digunakan dalam penelitian ini berupa soal tes dan lembar wawancara. Data yang diperoleh dianalisis dengan langkahlangkah (1) Mereduksi data. (2) menyajikan data dan (3) menarik kesimpulan. Hasil penelitian ini yaitu S1 lebih banyak mengalami kesalahan pseudo construction "benar" dan mis-logical construction dengan scaffolding yang diberikan yaitu level 2 (reviewing, explaining dan restructuring) sedangkan S2 mengalami keempat bentuk kesalahan dengan scaffolding yang diberikan adalah scaffolding level 2. pemberianScaffolding pada setiap individu akanlah berbeda karena harus disesuaikan dengan zona perkembangan aktualnya masing-masing. 


\section{INTRODUCTION}

Mathematical problem solving ability plays an important role in learning mathematics [1]-[3]. Students can upgrade higher order thinking skills by applying problem solving-based mathematics learning. Mathematical problem solving can also stimulate the improvement of students' specific skills that help students understand the relationship between concepts, cultivate perseverance and curiosity, and develop students' self-confidence in dealing with problems [4], [5].

According to Sánchez-Barbero's opinion, one of the important cognitive tasks that must be implemented in the classroom is problem solving [6], [7]. This ability is one of the most relevant aspects of curricula in many countries and an educational competency that is taken into account in international assessment frameworks (e.g., International Trends in Mathematics and Science Studies, TIMSS; Program for International Students International Assessment, PISA or National Assessment of Educational Progress, NAEP). This ability gives students the knowledge and skills to deal with everyday problem situations or non-routine problems [8].

However, the reality shows that students' mathematical problem solving abilities are still not satisfactory. Based on research conducted by Subanji, it is known that students often experience errors in constructing concepts. An error that often occurs is when students make a problem-solving model but cannot solve it properly. Students are not used to solving uncommon problems. Several factors that cause this problem include thinking errors in making connections, insufficient prior knowledge, and incomplete procedural thinking processes [9], [10].

In solving mathematical problems, students still often make mistakes, especially in constructing concepts. There are many incidents where students can only 'calculate mathematically' but have not been able to solve problems. Because what is really needed in everyday life is the ability to solve problems, not just do quick calculations [9], [11]. So that it can cause students to experience concept construction errors in solving mathematical problems.

Subanji stated that the forms of students' conceptual construction errors were pseudo construction, construction hole, incorrect analogy construction, and logical construction error. Students experience pseudo construction consisting of two forms, true and false, then construction hole occurs when the ability of the thinking structure form is not intact. Analogical construction errors occur because students assume all concepts are the same. And students experience a logical construction error when students experience errors in logical thinking and do not understand a problem presented [9].

When students carry out mathematical problem-solving activities, there are errors in the construction of concepts they understand, therefore these errors need to be taken seriously. To correct the error in the construction of the concept, assistance or reinforcement from the teacher or supervisor is needed in the form of reinforcement or scaffolding that is in accordance with the circumstances and needs of students.

According to Wood, Bruner, \& Ross scaffolding can be defined as a process that allows a child or student to solve problems, carry out tasks, or achieve goals that will surpass him/herself [12]. According to Miyazaki, the scaffolding process can motivate students in problem-solving procedures, the scaffolding process will increase students' confidence in solving mathematical problems, and this method can show students' mistakes and misunderstandings in the solving procedure [13]-[15]. Another idea that affects scaffolding is the zone of proximal development (ZPD). ZPD is the distance between actual developmental level by independent problem solving and potential development level through problem-solving under adult guidance, or in collaboration with 
more capable peers [16]. In addition to the ZPD, the scaffolding has several levels in providing assistance, namely environmental provisions, the second level is explaining, reviewing and restructuring, and the last level is developing conceptual thinking [17], [18].

Based on previous research, it was found that most teachers provided scaffolding in the form of explaining, reviewing, and restructuring [13]. Meanwhile, recent research shows that good scaffolding should be able to help and improve computational thinking processes because giving questions, instructions, reminders, directions, or encouragement makes students' computational thinking optimally active [19].

From several previous studies, it can be seen that scaffolding has many benefits, especially to improve thinking skills. The difference between this study and previous research is that this research focuses on students' thinking processes in solving mathematical problems by looking at the concept construction errors seen from the think aloud process and added by open interviews with research subjects. Giving scaffolding in the problem solving process is very important and good for students because it can reduce the forms of students' concept construction errors. Giving scaffolding to students aims to help students to overcome conceptual errors in solving math problems [20], [21]. Therefore, every teacher must understand the concept and how to provide the correct scaffolding so that the results are maximal.

\section{METHOD}

This research is included in the type of qualitative research. According to Creswell, qualitative research is a method for exploring and understanding the meaning of social or humanitarian problems [22]. This research process involves important efforts, such as interviews, collecting specific data from the participants, analyzing the data, and interpreting the meaning of the data. Data analysis consists of 3 stages: 1) Data reduction, selecting and classifying students who make mistakes in constructing concepts. The initial subjects in this study amounted to 6 people after reducing the subject data that met the problem solving indicators into 2 students with moderate and low abilities. (2) The presentation of the data is to arrange the types of errors made by students based on the concept construction errors in problem solving problems. (3) Drawing conclusions. Figure 1 shows the flow of the research procedure.

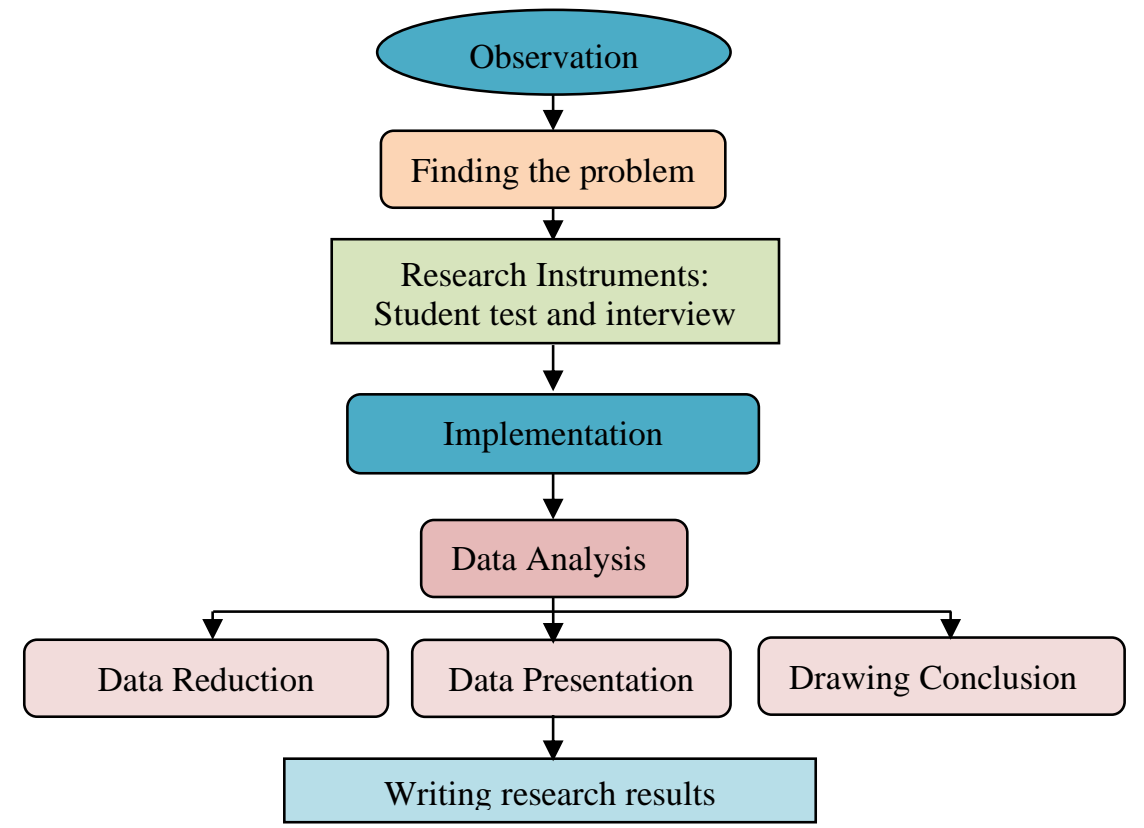

Figure 1. Qualitative Research Flowchart [23] 
The subject selection technique in this study was purposive sampling. The subjects in this study were two grade 12 students at SMA Islam Al-Arief Jambi with category 1 student with low math ability (S1) and 1 student with moderate math ability (S2). There are two types of instruments used in this study. The main instrument is the researcher himself who acts to design, collect data, analyze data, interpret data, and record research results. The supporting instruments used in this research are problem solving ability tests and interviews.

\section{RESULTS AND DISCUSSION}

The data generated in this study were sourced from the results of the problem-solving ability test and the results of open interviews. Research subjects work on the questions given by doing think aloud. From the results of the interview, it was found that various forms of concept construction errors were found, from the concept construction errors the researchers provided scaffolding based on the level according to the needs.

\subsection{Analysis of Concept Construction Errors in S1 in Solving Problems and the Process of Providing Scaffolding.}

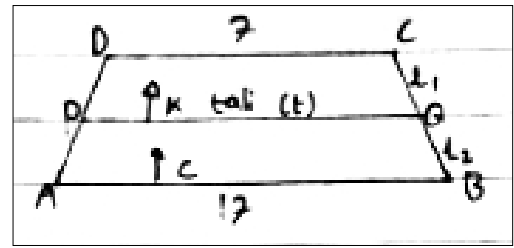

Figure 2. S1 Work Result in Understanding Problems

Based on Figure 2, it can be seen that S1 has understood the problem and the content of the questions well, but S1 did not write down the known information and the problems asked. After the researcher conducted the interview, it was found that S1 admitted that he forgot to write down the two stages. The error experienced by S1 is the "wrong" pseudo construction and the researcher provides scaffolding in the form of explaining, namely by explaining that writing down the information that is known and the problem being asked is an important thing in the steps to solving problem solving problems.

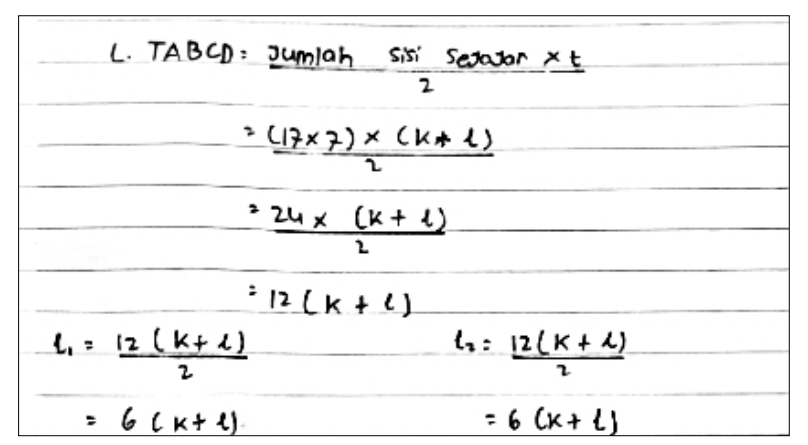

Figure 3. Result of S1 Work in Planning Problem Solving

Based on Figure 3, S1 begins to plan a solution by writing down the area of the trapezoid which is $12(\mathrm{k}+\mathrm{l})$ then $\mathrm{S} 1$ continues the work by dividing the area of the trapezoid into two, which is $\mathrm{L}_{1}=\frac{12(\mathrm{k}+\mathrm{l})}{2}=6(\mathrm{k}+\mathrm{l})$ and $\mathrm{L}_{2}=\frac{12(\mathrm{k}+\mathrm{l})}{2}=6(\mathrm{k}+\mathrm{l})$, which means that the area is the same. However, the student experienced an error in the construction of the "correct" pseudo construction concept when explaining the concept of 
height in the trapezoid. When asked why the height of the trapezoid was replaced with $\mathrm{k}+$ 1 while the area of the trapezoid to be divided was the same, S1 could not answer and was silent. From the results of the interview, it can be seen that S1 still cannot explain the concept of height in a spatial structure even though the answers written are correct, so the researcher provides scaffolding in the form of restructuring by simplifying a concept of height in a two-dimensional figure with different examples to make it simpler and more acceptable for students.

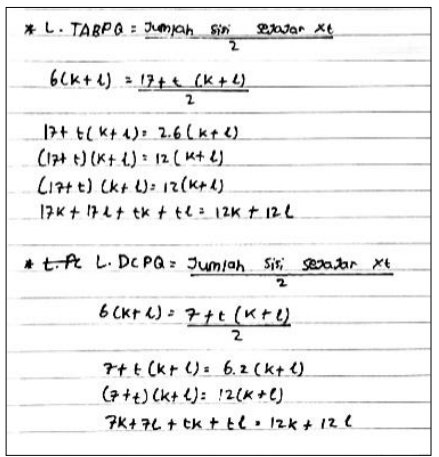

Figure 4. The Results of S1 Work in Solving Problems

Based on Figure 4, it can be seen that $\mathrm{S} 1$ solves the problem by finding each unknown component using the known area of the trapezoid. However, while working, S1 made a mistake, so that the results obtained are not as they should be $\mathrm{L}_{1} A B P Q=$ $\frac{\text { number of } 2 \text { parallel sides } \times t}{2} \rightarrow 6(k+l)=\frac{17+t(k+l)}{2}$ where it should be $\mathrm{L}_{1} A B P Q=$ $\frac{\text { number of } 2 \text { parallel sides } \times t}{2} \rightarrow 6(k+l)=\frac{17+t(l)}{2}$. S1 is wrong in substituting the high value in the trapezoid ABPQ where it should be 1 but $S 1$ wrote $k+1$. So it can be seen that $S 1$ made a concept construction error, Mis-Logical Construction because students gave wrong answers which resulted in students not being able to reason and understand the questions correctly, then the researcher provided scaffolding in the form of explaining, namely by conveying the actual concept to $\mathrm{S} 1$.

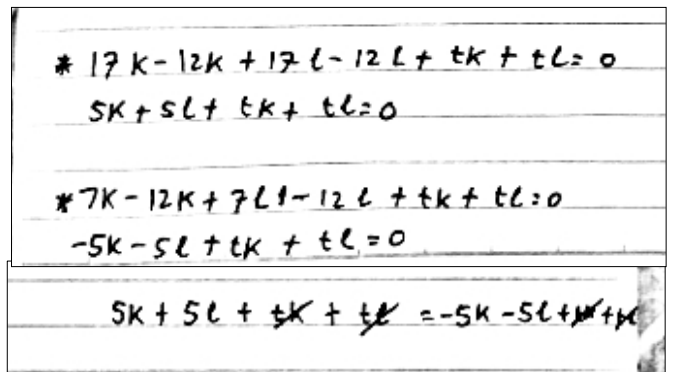

Figure 5. The Result of S1 Work in Solving Problems

Based on Figure 5, the steps taken by S1 were correct but when interviewed about the concept students seemed to have conceptual construction errors, when S1 equated the results of the area of trapezoid 1 and trapezoid 2 by using the term "crossed out". In the interview, the researcher asked the reason why there were numbers that crossed out. Then S1 answered "I can cross out the numbers because the values are the same". From these answers, it appears that S1 experienced a concept construction error in the form of a Construction Hole because what the students wrote was correct but the reason was wrong. Therefore, the researcher provides scaffolding in the form of explaining by explaining the real concept of linear equations. 


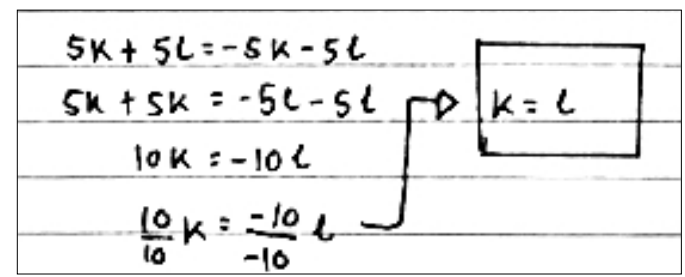

Figure 6. S1 Work Result in Reviewing Answers

Based on Figure 6, it can be seen that S1 did not find the right answer, where the correct answer was the length of rope $(\mathrm{t})$ required but $\mathrm{S} 1$ answered $\mathrm{k}=\mathrm{l}$. When the researcher asked why $\mathrm{S} 1$ wrote $\mathrm{k}$ equal to $\mathrm{l}, \mathrm{S} 1$ reasoned because it was wrong from the start. Actually, there is an error when S1 assumes the height for the area of trapezoid 1 and area of trapezoid 2 with $k+1$, which should be $k$ for the area of trapezoid1 and 1 for trapezoid 2. At this stage the researcher provides scaffolding in the form of reviewing by revisiting and identifying aspects problem to be solved.

\subsection{Analysis of Concept Construction Errors in S2 in Solving Problems and the Process of Providing Scaffolding}

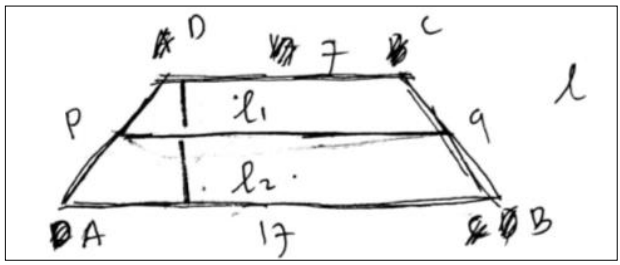

Figure 7. Results of S2 Work in Understanding Problems

Based on Figure 7, it can be seen that S2 understands the questions given. S2 describes the trapezoidal shape first and writes the names of the vertices of each. In Figure 6 it can be seen that there are several writings of the name of the vertices. In the interview, $\mathrm{S} 2$ told that at the beginning of the work S2 made a mistake in placing the name of the vertices where the PQ side should be parallel to the side AB but S2 actually made the point $\mathrm{P}$ not on the $\mathrm{AD}$ side so that the two lines became a line that crossed while in the problem, the line had to divide trapezoid into two equal parts. This error is classified as a "correct" pseudo construction because at first the student's steps looked right, but when it was traced it turned out that what the student was doing was wrong. So the researchers provided scaffolding in the form of reviewing by asking students to read the names of the trapezoidal shapes that had been made sequentially.

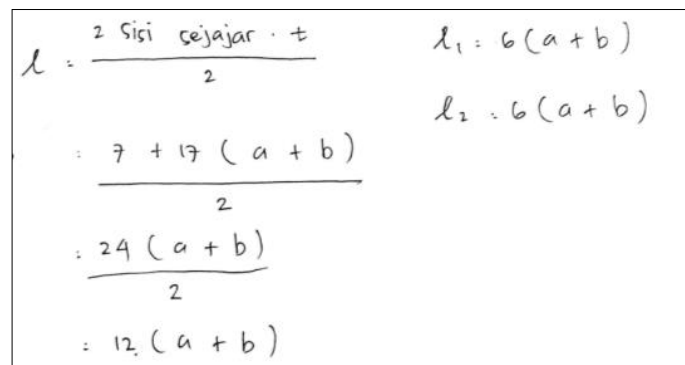

Figure 8. The Result of S2 Work in Planning Problem Solving

Based on Figure 8, S2 plans to solve the problem by finding the area of the trapezoid with a known value. However, it can be seen that $\mathrm{S} 2$ wrote the formula for the area of a trapezoid with a sentence that initially looked correct but had the wrong meaning so that S2 
experienced a construction error in the concept of the construction hole shape. The formula for the area of a trapezoid that should be $\frac{\text { number of } 2 \text { parallel sides } \times \text { height }}{2}$, but S2 wrote it as $\frac{2 \text { parallel sides } \times t}{2}$. Looks similar but has a different meaning. During the interview, S2 admitted that he knew what he meant but forgot when he was going to write down the correct formula, so the researcher provided scaffolding in the form of explaining by explaining the concepts that had been learned.

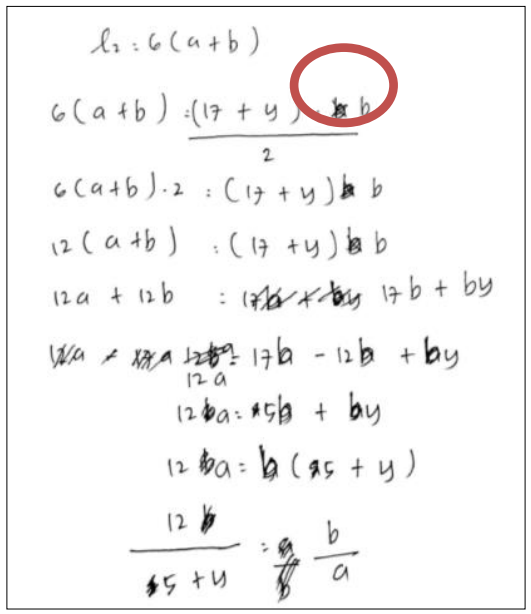

Figure 9. The Result of S2 Work in Reviewing Answers

Based on Figure 9, it can be seen that S2 has a concept construction error where students assume that the heights of the two upper and lower trapezoids are the same because in the written problem the two areas are the same. So that at this stage students experience a form of "mis-logical construction" error because students cannot reason about the questions given correctly. Knowing this, the researcher provides scaffolding explaining by re-explaining the concepts that have been studied.

Not only that, then students make mistakes again in the next working step by equating the high symbol on the second trapezoid (b) with the height on the first trapezoid (a), students wrote $6(a+b) 2=(17+y) a$ the height of the trapezoid should be changed to just $b$ because it is assumed that the heights of the two trapezoids are different. This includes errors in the construction of the concept of mis-analogical construction because students equate one concept with another. Therefore, researchers provide scaffolding in the form of reviewing by asking students to observe the picture and compare it with the work result to find out where the error is.

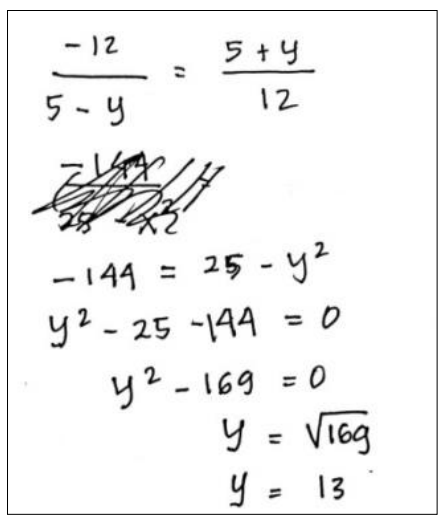

Figure 10. The Results of S2 Work in Re-checking the Answers 
Based on Figure 10, S2 experienced a concept construction error when doing the cross product of two equations where the equations should be $\mathrm{y}^{2}-25-144=0$ but initially the students wrote it as $\frac{-144}{25-y^{2}}$ it is a serious error because students are wrong in constructing the concept of cross multiplication, this form of error is a mis-analogical construction and seeing this the researcher gives an explanation related to this in the form of explaining by conveying the concepts learned. Table 1 shows a summary of the results of interviews with subjects $\mathrm{S} 1$ and $\mathrm{S} 2$.

Table 1. Results of Analysis Based on Interviews with S1 and S2 Subjects

\begin{tabular}{|c|c|c|c|c|}
\hline \multirow[b]{2}{*}{$\begin{array}{c}\text { Problem Solving } \\
\text { Stage }\end{array}$} & \multicolumn{2}{|c|}{ First Subject (S1) } & \multicolumn{2}{|c|}{ Second Subject (S2) } \\
\hline & $\begin{array}{c}\text { Concept } \\
\text { Construction Error }\end{array}$ & Scaffolding & $\begin{array}{c}\text { Concept } \\
\text { Construction Error }\end{array}$ & Scaffolding \\
\hline $\begin{array}{l}\text { Understand the } \\
\text { problem }\end{array}$ & $\begin{array}{c}\text { Pseudo Construction } \\
\text { "Wrong" }\end{array}$ & Explaining & $\begin{array}{l}\text { Pseudo Construction } \\
\text { "Correct" }\end{array}$ & Reviewing \\
\hline Planning the problem & $\begin{array}{l}\text { Pseudo Construction } \\
\text { "Correct" }\end{array}$ & Restructuring & Construction Hole & Explaining \\
\hline Solving the problem & $\begin{array}{l}\text { Mis-Logical } \\
\text { Construction }\end{array}$ & Explaining & $\begin{array}{l}\text { Mis-Logical } \\
\text { Construction }\end{array}$ & Explaining \\
\hline & Construction Hole & Explaining & $\begin{array}{l}\text { Mis-Analogical } \\
\text { Construction }\end{array}$ & Reviewing \\
\hline $\begin{array}{l}\text { Review the work } \\
\text { results }\end{array}$ & $\begin{array}{l}\text { Mis-Logical } \\
\text { Construction }\end{array}$ & Reviewing & $\begin{array}{l}\text { Mis-Analogical } \\
\text { Construction }\end{array}$ & Explaining \\
\hline
\end{tabular}

Based on the results of the analysis above, it can be seen that for S1 and S2 scaffolding that can be given is only up to level 2, namely explaining, reviewing, and restructuring. And level 1 is the developing environment which is done before students work on the questions. Based on the results of the study, the subject with the low ability (S1) has fulfilled 4 problem-solving indicators, but in the process of S1 often makes mistakes when entering the value of a variable so that it affects the final result. This happened because of an error in the completion strategy which resulted in logical thinking errors so that students experienced a form of mis-logical construction error. This is also in accordance with Subanji's opinion which states that an indication of someone experiencing a logical thinking error is because the student has an error in formulating a problem solving strategy [9], [24], [25].

Meanwhile, subjects with moderate ability (S2) have fulfilled the four problemsolving indicators properly and correctly and the final results obtained are also correct, but in the interview process there are still construction holes, "correct" pseudo construction, mis-analogical construction and mis-logical construction. . From this, each scaffolding given is also different according to the development of the student's way of thinking. This is in accordance with Vygotsky's opinion that every student has a Zone of Proximal Development (ZPD), which is the distance between the actual level of development determined by independent problem solving and the level of potential development determined by problem solving under adult guidance, or in collaboration with colleagues who are more capable [26][27]. Therefore, the scaffolding for each student must be different, because it should be given according to the needs and the development of each student's ability. This is in line with the results of previous researches which stated that [28], [29]. Scaffolding is a practice based on Vgyotsky's concept of the ZPD which can be interpreted as the Nearest Development Area [14], [30]. 


\section{CONCLUSION}

Based on the results of the study, it was found that the two subjects often experienced various conceptual construction errors in solving problems, although there were subjects who did not experience all forms of concept construction errors. Different forms of concept construction errors require different scaffolding, according to their level of development. ZPD is one of the benchmarks in providing scaffolding to each student because each student has a different ZPD. As for suggestions for further research, it is better to use more subjects and with broader lessons. The aim is to increase knowledge related to the provision of scaffolding.

\section{REFERENCES}

[1] L. A. Mahromah and J. T. Manoy, "Identifikasi Tingkat Metakognisi Siswa Dalam Memecahkan Masalah Matematika Berdasarkan Perbedaan Skor Matematika," MATHEdunesa, vol. 2, no. 1, 2013.

[2] J. Novotná, P. Eisenmann, J. Přibyl, J. Ondrušová, and J. Břehovský, "Problem Solving in School Mathematics Based on Heuristic Strategies," J. Effic. Responsib. Educ. Sci., vol. 7, no. 1, pp. 1-6, 2012, doi: 10.7160/eriesj.2013.070101.Introduction.

[3] S. Gembong, "Schema building profiles among elementary school students in solving problems related to operations of addition to fractions on the basis of mathematic abilities," Journal of Physics: Conference Series, vol. 983, no. 1. 2018, doi: 10.1088/1742-6596/983/1/012155.

[4] N. R. Dewi, "Peningkatan Kemampuan Koneksi Matematis Mahasiswa Melalui Brain-Based Learning Berbantuan Web," Pros. SNMPM Univertas Sebel. Maret 2013, vol. 1, p. 284, 2013.

[5] W. Rahmawati, "Validation of learning devices guided inquiry-based to increase problem solving ability mathematic participants in class VII SMP," Journal of Physics: Conference Series, vol. 1317, no. 1. 2019, doi: 10.1088/17426596/1317/1/012135.

[6] R. Sari, T. A. Kusmayadi, and I. Sujadi, "Aktivitas metakogonisi dalam pemecahan masalah matematika ditinjau dari gender siswa kelas VII SMP negeri 1 nanggulan kabupaten kulon progo," J. Elektron. Pembelajaran Mat., vol. 4, no. 5, pp. 496509, 2016, [Online]. https://jurnal.uns.ac.id/jpm/article/viewFile/10916/9792.

[7] L. Vendiagrys and I. Junaedi, "Analisis Kemampuan Pemecahan Masalah Matematika Soal Setipe Timss Berdasarkan Gaya Kognitif Siswa Pada Pembelajaran Model Problem Based Learning," Unnes J. Res. Math. Educ., vol. 4, no. 1, pp. 34-41, 2015.

[8] B. Sánchez-Barbero, J. M. Chamoso, S. Vicente, and J. Rosales, "Analysis of teacher-student interaction in the joint solving of non-routine problems in primary education classrooms," Sustain., vol. 12, no. 24, pp. 1-13, 2020, doi: $10.3390 /$ su122410428.

[9] S. Subanji, Teori Kesalahan Konstruksi Konsep dan Pemecahan Masalah Matematika, 1st ed. semarang: Universitas Negeri Malang, 2015.

[10] S. Wulandari, "Defragmentation of Preservice Teacher's Thinking Structures in Solving Higher Order Mathematics Problem," Journal of Physics: Conference Series, vol. 1940, no. 1. 2021, doi: 10.1088/1742-6596/1940/1/012099.

[11] L. D. Haeruman, W. Rahayu, and L. Ambarwati, "Pengaruh Model Discovery Learning Terhadap Peningkatan Kemampuan Berpikir Kritis Matematis Dan Self- 
Confidence Ditinjau Dari Kemampuan Awal Matematis Siswa Sma Di Bogor Timur," J. Penelit. dan Pembelajaran Mat., vol. 10, no. 2, pp. 157-168, 2017, doi: 10.30870/jppm.v10i2.2040.

[12] A. Bakker, "Scaffolding and dialogic teaching in mathematics education: introduction and review," ZDM - Math. Educ., vol. 47, no. 7, pp. 1047-1065, 2015, doi: 10.1007/s11858-015-0738-8.

[13] Warli, I. Cintamulya, and P. Rahayu, "Scaffolding process based on students diagnostic difficulties in proving group problems by using mathematics mapping," J. Phys. Conf. Ser., vol. 1422, no. 1, 2020, doi: 10.1088/1742-6596/1422/1/012012.

[14] N. Ismail, "The effect of maternal scaffolding on problem solving skills during early childhood," J. Behav. Sci., vol. 14, no. 3, pp. 76-89, 2019, [Online]. Available: https://www.scopus.com/inward/record.uri?partnerID=HzOxMe3b\&scp=8507600 $1598 \&$ origin=inward.

[15] E. Yuriev, "Scaffolding the development of problem-solving skills in chemistry: Guiding novice students out of dead ends and false starts," Chem. Educ. Res. Pract., vol. 18, no. 3, pp. 486-504, 2017, doi: 10.1039/c7rp00009j.

[16] I. Testad, A. Corbett, and D. et al Aarsland, “ORE Open Research Exeter," J. Clean. Prod., 2013.

[17] J. Anghileri, "Scaffolding practices that enhance mathematics learning," J. Math. Teach. Educ., vol. 9, no. 1, pp. 33-52, 2006, doi: 10.1007/s10857-006-9005-9.

[18] L. Mamykina, "Structured scaffolding for reflection and problem solving in diabetes self-management: Qualitative study of mobile diabetes detective," J. Am. Med. Informatics Assoc., vol. 23, no. 1, pp. 129-136, 2016, doi: 10.1093/jamia/ocv169.

[19] M. G. Supiarmo, L. Mardhiyatirrahmah, and T. Turmudi, "Pemberian Scaffolding untuk Memperbaiki Proses Berpikir Komputasional Siswa dalam Memecahkan Masalah Matematika," J. Cendekia J. Pendidik. Mat., vol. 5, no. 1, pp. 368-382, 2021, doi: 10.31004/cendekia.v5i1.516.

[20] Komarudin, "Analisis Kesalahan Pemecahan Masalah Matematika pada Materi Peluang Berdasarkan High Order Thinking," J. Pendidikan, Komun. dan Pemikir. Huk. Islam, vol. VIII, no. 1, pp. 202-217, 2016.

[21] M. Ulu, "Errors made by elementary fourth grade students when modelling word problems and the elimination of those errors through scaffolding," Int. Electron. J. Elem. Educ., vol. 9, no. 3, pp. 553-580, 2017.

[22] J. W. Creswell, Reaserch Design Pendekatan Metode Kualitatif, Kuantitatif dan Campuran. Yogyakarta: Pustaka Pelajar, 2013.

[23] Sugiyono, Metode Penelitian Kuantitatif. Bandung: Alfabeta, 2018.

[24] M. Hutajulu, E. Senjayawati, and E. D. Minarti, "Analisis Kesalahan Siswa SMK Dalam Menyelesaikan Soal Kecakapan Matematis Pada Materi Bangun Ruang," Mosharafa J. Pendidik. Mat., vol. 8, no. 3, pp. 365-376, 2019.

[25] S. A. Widodo, "Analisis Kesalahan Dalam Pemecahan Masalah Divergensi Tipe Membuktikan Pada Mahasiswa Matematika," J. Pendidik. Dan Pengajaran, vol. 46, no. 2, pp. 106-113, 2013, [Online]. Available: dodok_chakep@yahoo.com.

[26] I. Kusmaryono, "Construction of students' mathematical knowledge in the zone of proximal development and zone of potential construction," Eur. J. Educ. Res., vol. 10, no. 1, pp. 341-351, 2021, doi: 10.12973/eu-jer.10.1.341.

[27] F. Rahmawati, "Pengaruh Pendekatan Pendidikan Realistik Matematika dalam Meningkatkan Kemampuan Komunikasi Matematis Siswa Sekolah Dasar," Pros. SEMIRATA 2013, vol. 1, no. 1, pp. 225-238, 2013, [Online]. Available: http://jurnal.fmipa.unila.ac.id/index.php/semirata/article/view/882. 
[28] F. M. Nabila and A. Gani, "Pengaruh Penerapan Strategi Scaffolding Terhadap Ketuntasan Hasil Belajar Peserta Didik SMA Negeri 4 Banda Aceh Pada Submateri Tata Nama Senyawa Hidrokarbon," vol. 6, no. 2, pp. 1310-1316, 2017.

[29] A. Bayuningsih, "Problem based learning with scaffolding technique on geometry," Journal of Physics: Conference Series, vol. 1013, no. 1. 2018, doi: 10.1088/17426596/1013/1/012134.

[30] M. J. Barrett, "Learning for transdisciplinary leadership: Why skilled scholars coming together is not enough," Bioscience, vol. 69, no. 9, pp. 736-745, 2019, doi: 10.1093/biosci/biz072. 